\title{
СПОСОБ НЕПРЕРЫВНОГО ВОССТАНОВИТЕЛЬНОГО \\ АЛКИЛИРОВАНИЯ НИТРОБЕНЗОЛА КАРБОНИЛЬНЫМИ СОЕДИНЕНИЯМИ
}

\author{
В.М. Мохов, С.Е. Латышова, А.В. Разваляева, А.О. Панов, \\ Ю.В. Попов \\ 1Волгоградский государственный технический университет, \\ 400005, Россия, г. Волгоград, пр-кт им. В.И. Ленина, 28.
}

DOI: 10.19163/MedChemRussia2021-2021-231

E-mail: tons@vstu.ru

Производные анилина получили широкое применение в качестве полупродуктов в синтезе фармакологических препаратов, красителей и др. Перспективным методом получения $\mathrm{N}$-алкиланилинов является восстановительное алкилирование нитробензола карбонильными соединениями, при котором восстановление нитробензола в анилин, образование иминов с карбонильным соединением и их гидрирование во вторичный амин протекают в одном реакторе и на одном катализаторе.

Нами разработан непрерывный способ $\mathrm{N}$-алкиланилинов в проточном реакторе на доступных катализаторах, состоящий в пропускании смеси нитробензола, карбонильного соединения и водорода через слой гетерогенного катализатора. Катализаторы приготовлялись пропиткой водным раствором $\mathrm{NiCl}_{2}$ носителя $\gamma-\mathrm{Al}_{2} \mathrm{O}_{3}$ или $\mathrm{MgO}$ с последующим восстановлением $\mathrm{NaBH}_{4}$ в воде.<smiles>O=[N+]([O-])c1ccccc1</smiles>

1a

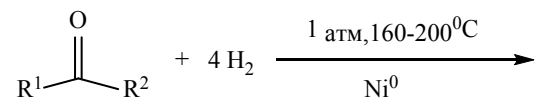

2а-д<smiles>[R]C([R])Nc1ccccc1</smiles>

$$
\mathrm{R}^{1}=\mathrm{H}: \mathrm{R}^{2}=\mathrm{Et}(2 \mathrm{a}, 3 \mathrm{a}),{ }^{\mathrm{i}-\operatorname{Pr}}(26,36), \mathrm{Fu}(2 \mathrm{z}, 3 \text { в }) ; \mathrm{R}^{1}=\mathrm{R}^{2}=\mathrm{Me}(2 г, 3 г), \mathrm{R}^{1}-\mathrm{R}^{2}=\left(\mathrm{CH}_{2}\right) 5 \text { (2д, 3д) }
$$

Выходы целевых продуктов достигали 98\% при $180-220^{\circ} \mathrm{C}$ и атмосферном давлении водорода. Способ может быть применен для малотоннажного синтеза $\mathrm{N}$-алкиланилинов в производстве фармакологических средств. 